\title{
The Role of Saprotrophy and Virulence in the Population Dynamics of Botrytis cinerea in Vineyards
}

\author{
Fabian Martinez, Bernadette Dubos, and Marc Fermaud
}

Unité Mixte de Recherches en Santé Végétale INRA-ENITAB, Institut National de la Recherche Agronomique (INRA), BP 81, 33883

Villenave d'Ornon cedex, France.

Accepted for publication 11 February 2005.

\begin{abstract}
Martinez, F., Dubos, B., and Fermaud, M. 2005. The role of saprotrophy and virulence in the population dynamics of Botrytis cinerea in vineyards. Phytopathology 95:692-700.

Change in relative frequencies of the three main genetic types of Botrytis cinerea (Group I, Group II vacuma, and Group II transposa) were monitored over time from 1998 to 2000 in three Bordeaux vineyards not treated with fungicides. During 2000, Group I isolates, detected mostly at flowering comprised only $2.5 \%$ of the entire population. Within Group II, the complementary frequencies of vacuma and transposa isolates differed significantly depending on grapevine phenological stages

frequency of vacuma isolates reached a maximum on senescing floral caps (between 23.5 and $71.4 \%$ ) and then decreased significantly until harvest on leaves and berries. In pathogenicity tests on grape berries, transposa isolates were significantly more virulent than were vacuma isolates. Mycelial growth rate was negatively correlated with virulence, notably on leaves in transposa and with double resistance to the fungicides carbendazim and vinclozolin. In vacuma, this double resistance was positively correlated with virulence on leaves. Change in the vacuma and transposa frequencies was most likely caused by differences in saprotrophic and pathogenic fitness. Possible interactions between fungicide resistance profiles and fitness are discussed.
\end{abstract} and organs. Every year and at all sites, including one noble rot site, transposa isolates dominated at every stage, particularly on overwintering canes and at harvest (greater than $86.7 \%$ on berries). The complementary
Additional keywords: epidemiology, fitness, fungicide resistance, gray mold, noble rot.
Botrytis cinerea Pers.:Fr. (teleomorph Botryotinia fuckeliana (de Bary) Whetzel) is a cosmopolitan filamentous fungus and necrotrophic pathogen (19) attacking over 200 different plant species (23). In many vineyards around the world, $B$. cinerea causes one of the most serious diseases of aerial grapevine (Vitis vinifera L.) organs, Botrytis bunch rot, which can drastically reduce yield at harvest and wine quality, especially for red wines (4). However, B. cinerea infestation can also be desirable as "noble rot" when present on grape cultivars where sweet, late harvest wines are produced (49).

$B$. cinerea is phenotypically diverse with respect to its morphology, mycelial growth, sporulation intensity, virulence, enzyme production, or fungicide resistance $(6,8,29,37,58)$ as well as genetically diverse $(5,9,20,56)$. Various studies have investigated different phenotypic characteristics according to fungicide resistance because of the possibility of associated fitness costs $(22,36$, 47,48,59). However, attempts to relate genetic pattern (e.g., using random amplified polymorphic DNA [RAPD]) with phenotypic or fitness components have been generally unsuccessful $(25,55)$ with the exception of trends concerning host specialization or fungicide resistance $(38,53)$.

In the vineyard and on various host plants, $B$. cinerea was considered as a complex of sympatric species (16-18). According to recent phylogenetic analyses (14), two main genetic types, namely "Group I" and "Group II", have been distinguished on the basis of having a greater genetic dissimilarity compared with the genetic variability within Group II (i.e., between vacuma and transposa). However, neither has been described as a species different from B. cinerea. Consequently, the term "genetic type" is

Corresponding author: F. Martinez; E-mail address: martinez@bordeaux.inra.fr

DOI: 10.1094/PHYTO-95-0692

(c) 2005 The American Phytopathological Society used throughout this paper referring to populations with significant genetic dissimilarity from each other but remaining within the species $B$. cinerea. Group I forms a vegetative compatibility group in which isolates are insensitive to fenhexamid, a new botryticide $(1,14,26)$. Group II isolates have been further divided into two types, transposa and vacuma (17). The presence of both transposable elements, Boty (9) and Flipper (31), is a characteristic feature of the transposa genome. These types have also been studied according to other molecular markers (16), i.e., polymerase chain reaction (PCR)-restriction fragment length polymorphism (RFLP) and length of the minisatellite MSB1 (15). Moreover, marked phenotypic differences between vacuma and transposa have been demonstrated. Transposa isolates have (i) smaller macroconidia (17), (ii) are more frequently resistant to vinclozolin and diethofencarb (16), and (iii) exhibit slower rates of mycelial extension when grown on highly nutritive agar media at different favorable temperatures (34). Lastly, in the Champagne vineyards, anecdotal observations suggest a decline in the frequency of vacuma isolates during the summer months (17). Possible changes in frequency of $B$. cinerea types over time could explain, in France but not Australia (41), why levels of inoculum at flowering were not correlated with disease levels at harvest (13).

Ecological fitness components that dictate saprotrophic and parasitic capability are an important determinant of population dynamics and life strategy (46). By postulating that the mycelial growth rate on a highly nutritive medium constitutes a measure of saprophytic potential for colonization, it is hypothesized that vacuma isolates will express a more ruderal life-strategy (" $\mathrm{r}$ strategy") with greater saprophytic capability than will the transposa isolates $(34,46)$. In this paper, our main objective is to examine the extent to which the trade off between saprophytic and pathogenic capabilities can be related to differences in the population dynamics between vacuma and transposa types of $B$. cinerea. In addition, we examined an alternative hypothesis that these dif- 
ferences are related to differences in fungicide resistance and associated fitness costs. The results are used to discuss the extent to which these mechanisms may play a major role in dictating the population dynamics of $B$. cinerea in French vineyards.

\section{MATERIALS AND METHODS}

Population dynamics, isolation, culture, and storage conditions of $\boldsymbol{B}$. cinerea. To examine changes in the relative frequency of the different $B$. cinerea types over time and on various organs of the grapevine, samples of $B$. cinerea isolated from three traditionally managed vineyards near Bordeaux were studied. A total of 741 isolates (Table 1) were collected. Gray mold epidemics occurred in two locations: Medoc (St-Julien) on cv. Merlot noir and Graves (Pessac-Léognan) on cv. Sémillon. The third site was a vineyard located near Sauternes where $B$. cinerea lead to noble rot development (cv. Sémillon). One subplot (approximately 40 vines $\times 10$ rows) per site was used for sampling. The within-year dynamics were monitored at key epidemiological stages for three consecutive years, 1998, 1999, and 2000. During the 3 years, the subplots were investigated in the absence of anti-Botrytis fungicide application to avoid any direct effect of fungicide on population dynamics. However, from 1992 to 1998 in the surrounding vine plots there was the potential of a high selection pressure for fungicide resistance at flowering in response to application of the anti-Botrytis active ingredients, carbendazim and diethofencarb, and an intermittent selection pressure from veraison onward in response to applications of dicarboximide fungicides (iprodione, vinclozolin, or procymidone). During the growing season, isolates were collected from $B$. cinerea lesions on blossoms, grape berries, and leaves. During the winter, isolates originated from sclerotia at the surface of woody canes. Samples were collected at random with sterilized forceps. Each sample was incubated within a petri dish containing a wet filter paper. After incubation of infected tissues or sclerotia, the growing fungus was transferred to solid malt-agar medium (MA; $15 \mathrm{~g} /$ liter of Cristomalt, Materne, France and 20 g/liter of agar). Monoconidial isolates were then subcultured following single-spore isolation and stored in the dark at $4{ }^{\circ} \mathrm{C}$ on solid MA.

Molecular determination of the genetic types. Mycelia and conidia were harvested by scraping the surface of a pure culture of $B$. cinerea grown on MA. Genomic DNA was extracted with the method of Möller et al. (35). Molecular analysis was carried out with dot blot hybridizations for the detection of the transposable elements, Boty and Flipper, (17) and PCR to detect a Flipper insertion sequence specific to the transposa isolates (33).

Isolates belonging to Group I were identified with PCR-RFLP (14). All isolates collected in 2000 were tested, i.e., a total of 440 isolates originating from the three locations and isolated between flowering and winter.

Phenotypic characterization bioassays. In controlled conditions, key fitness components were investigated in 38 mono- conidial isolates collected in 1998, i.e., 19 vacuma isolates and 19 transposa isolates (Table 2). Isolates, originating from leaves and reproductive organs, were selected mostly from isolations made at veraison or harvest when gray mold symptoms develop most seriously. All isolates are available from authors upon request.

For examination of the saprotrophic capability of 30 isolates (Table 2), previously published data concerning mycelial growth tests were used (34). The data describing mean daily radial growth in centimeters per day had been obtained from two trials on MA plates at $20^{\circ} \mathrm{C}$.

For examination of virulence, data was used from two sources. For virulence on leaf discs, previously published data were used for 27 isolates (17 transposa and 10 vacuma) (34). The overall mean foliar virulence index resulted from three trials, each including the two species Nicotiana clevelandii and $V$. vinifera $\mathrm{cv}$. Cabernet Sauvignon (35). For virulence on grape berries, virulence of 38 isolates (19 transposa and 19 vacuma) (Table 2) was tested using grape berries of $V$. vinifera cvs. Sauvignon and Merlot noir. Berries harvested at random were collected from vine plots untreated with anti-Botrytis fungicides and located on the INRA experimental vineyard at Villenave d'Ornon near Bordeaux. Two or three berries per bunch were removed individually with the pedicel attached to avoid risk of wounding. To remove residues that might be used as a nutrient source by $B$. cinerea, berries were rinsed in sterile deionized water and then dried. Three trials, each corresponding to a different maturity stage of berries (bunch closure, mid-veraison, and maturity) and each including both cultivars, were carried out. Sixteen berries, eight from the top and eight from the bottom of bunches, were inoculated per treatment (isolate/cultivar/maturity combination). Berries were placed, pedicel downward, on a grid within moist incubation chambers consisting of plastic boxes $(22 \times 13 \times 4 \mathrm{~cm})$ containing absorbent paper in the base with $15 \mathrm{ml}$ of sterile water. Each berry was wounded manually on the end opposite to the pedicel with a sterilized syringe needle. Mycelial plugs (4 $\mathrm{mm}$ in diameter) were cut from the edge of 4-day-old colonies of $B$. cinerea grown on MA plates at $20^{\circ} \mathrm{C}$ in the dark. The plugs were placed individually with mycelium in contact with the wound of the berry. The boxes containing inoculated berries were placed in an incubator (EX111; TABAI ESPEC CORP, Osaka, Japan) in the dark at a constant temperature of $20^{\circ} \mathrm{C}$ and relative humidity of $100 \%$. Symptom development was assessed on each berry according to a visual semiquantitative scale $(0=$ healthy, $1=10 \%$ rotten and not sporulating, $2=25 \%, 3=50 \%, 4=75 \%, 5=$ totally rotten sometimes slightly sporulating, and $6=$ totally rotten and sporulating). Different virulence indices were calculated at each maturity stage and for each cultivar: (i) a "berry incidence index" was calculated as the mean percentage of rotten berries; and (ii) a "berry severity index" was calculated as the mean rotten surface area per rotted berry (in the 1 to 6 scale). For each of these two components an overall berry virulence index was calculated as the overall mean, and by multiplying them, a global overall berry virulence index

TABLE 1. Overall sampling sizes in three vineyards

\begin{tabular}{|c|c|c|c|c|c|c|c|c|c|c|}
\hline \multirow[b]{2}{*}{ Period } & \multirow[b]{2}{*}{ Organ } & \multicolumn{3}{|c|}{ Médoc } & \multicolumn{3}{|c|}{ Graves } & \multicolumn{3}{|c|}{ Sauternes } \\
\hline & & 1998 & 1999 & 2000 & 1998 & 1999 & 2000 & 1998 & 1999 & 2000 \\
\hline \multirow[t]{2}{*}{ Bloom } & Leaves & 2 & 11 & 20 & $\ldots$ & $\ldots$ & 18 & $\ldots$ & $\ldots$ & 19 \\
\hline & Reproductive organs & 8 & 12 & 17 & 11 & $\ldots$ & 2 & $\ldots$ & 7 & 17 \\
\hline \multirow[t]{2}{*}{ Preveraison } & Leaves & $\ldots$ & $\ldots$ & 18 & 8 & $\ldots$ & $\ldots$ & $\ldots$ & $\ldots$ & $\ldots$ \\
\hline & Reproductive organs & $\ldots$ & $\ldots$ & 19 & 18 & $\ldots$ & $\ldots$ & $\ldots$ & $\ldots$ & $\ldots$ \\
\hline \multirow[t]{2}{*}{ Veraison } & Leaves & $\ldots$ & $\ldots$ & $\ldots$ & 10 & $\ldots$ & 21 & $\ldots$ & $\ldots$ & $\ldots$ \\
\hline & Reproductive organs & $\ldots$ & $\ldots$ & 16 & 20 & $\ldots$ & 19 & $\ldots$ & $\ldots$ & 20 \\
\hline \multirow[t]{2}{*}{ Postveraison } & Leaves & $\ldots$ & $\ldots$ & $\ldots$ & $\ldots$ & $\ldots$ & $\ldots$ & $\ldots$ & $\ldots$ & 23 \\
\hline & Reproductive organs & $\ldots$ & $\ldots$ & $\ldots$ & $\ldots$ & $\ldots$ & $\ldots$ & $\ldots$ & $\ldots$ & 21 \\
\hline \multirow[t]{2}{*}{ Harvest } & Leaves & 14 & 24 & 23 & 24 & $\ldots$ & 20 & $\ldots$ & $\ldots$ & 41 \\
\hline & Reproductive organs & 12 & 15 & 22 & 34 & 51 & 18 & 9 & $\ldots$ & 39 \\
\hline Winter & Woody canes & $\ldots$ & 18 & 10 & $\ldots$ & $\ldots$ & 10 & $\ldots$ & $\ldots$ & 19 \\
\hline
\end{tabular}


was obtained. Uninoculated control treatments were included by using MA plugs without the fungus and by testing wounded berries in the absence of inoculation.

To determine fungicide resistance profiles in vacuma and transposa, sensitivity to fungicides of $30 \mathrm{~B}$. cinerea isolates (11 vacuma and 19 transposa) was studied (Table 2). Three active ingredients, initially investigated by Giraud et al. (17), were tested on MPG medium (containing $10 \mathrm{~g}$ glucose, $1.5 \mathrm{~g} \mathrm{~K}_{2} \mathrm{HPO}_{4}, 2 \mathrm{~g}$ $\mathrm{KH}_{2} \mathrm{PO}_{4}, 1 \mathrm{~g}\left(\mathrm{NH}_{4}\right)_{2} \mathrm{SO}_{4}, 0.5 \mathrm{~g} \mathrm{MgSO}_{4}, \mathrm{H}_{2} \mathrm{O}, 2 \mathrm{~g}$ yeast extract, and $12.5 \mathrm{~g}$ agar in 1 liter.) (28) at the following discriminatory concentrations (27): carbendazim (10 mg/liter), diethofencarb (10 mg/liter), and vinclozolin ( $5 \mathrm{mg} / \mathrm{liter})$. The effect of carbendazim and diethofencarb was assessed by examining mycelial growth. Mycelial plugs (4 $\mathrm{mm}$ in diameter) removed from actively growing 4-day-old colonies on MA were placed, inverted, in the center of petri dishes containing the fungicide. The effect of vinclozolin was evaluated on germination rate of conidia (issued from sporulating cultures grown on MA for less than 10 days) after $24 \mathrm{~h}$ incubation at $20^{\circ} \mathrm{C}$ in the dark.

Statistical analyses. The $\mathrm{S}+$ software package was used for all statistical analyses (S-PLUS version 3.2; Statistical Sciences, Seattle, WA). Virulence on grape berries was determined by analysis of variance (ANOVA) performed separately for each berry maturity stage. A randomized factorial design based on 38 replicates was used with two main factors, type (vacuma versus transposa) and cultivar (Merlot versus Sauvignon). Each replicate corresponded to one isolate (19 per type) tested either on berries from the top or bottom of bunches. The sample correlation coefficients (Pearson $r$ ) were calculated using overall mean values per isolate calculated as previously described for the different variables. As for the virulence indices, means resulted from 48 data per isolate in leaf tests $(2$ hosts $\times 3$ trials $\times 8$ replicated leaf discs) and 96 in berry tests ( 2 cultivars $\times 3$ maturity stages $\times 16$ replicate berries). The difference in frequency of isolates between vacuma and transposa according to resistance to fungicides was tested at $P=0.05$ according to chi-square tests.

\section{RESULTS}

Frequency distribution of Group I isolates. Among the 440 isolates collected from symptomatic tissues in 2000, only 11 isolates belonged to Group I (i.e., $2.5 \%$ of the whole $B$. cinerea population). Nine of these isolates were detected on leaves and floral calyptras at flowering (three and three from the Médoc site and one and two from the Sauternes site, respectively). At veraison, only one isolate was found on leaves (Médoc) and one on berries (Graves). Lastly, no Group I isolate was found at harvest or during the following winter from overwintering canes.

Temporal distributions of Group II isolates (vacuma and transposa). The monitoring of relative frequencies of the two types vacuma and transposa confirmed their sympatry on the different grapevine organs throughout the year (Fig. 1). During the 3 years in the three experimental vineyards near Bordeaux the temporal dynamics were similar. Overall, the transposa isolates were more frequent, but this depended on the phenological stage and the grapevine organ from which the isolates were isolated. The frequency of transposa was significantly greater in isolates from sclerotia on canes during winter at all three locations (more than $70 \%$ of the whole population) (Fig. 1D, E, and F).

The frequency of transposa was greater than that of vacuma in most cases on blossoms (Fig. 1A, B, and C). There was only one exception (Sauternes in 1999) where the relatively small sample size $(n=7)$ may have caused such a discrepancy. At this stage, the frequency of vacuma isolates reached a maximum on senescing floral caps (from 23.5 to $71.4 \%$ depending on the site or the year). From veraison onward, there was a marked and significant difference in frequency distributions between the two types. Transposa isolates were clearly dominant on maturing berries. The corollary of this is that, at harvest, the vacuma isolates were present at a very low frequency, i.e., between 0 and $13.3 \%$ of the isolates from mature berries.

On leaves, similar dynamics to those on the reproductive organs were observed (Fig. 1D, E, and F). However, at harvest, the

TABLE 2. Origin of 38 single-spore isolates according to the genetic type of Botrytis cinerea collected in Bordeaux vineyards in 1998 and used for the phenotypic characterization

\begin{tabular}{|c|c|c|c|c|c|}
\hline Genetic type & Islolate no. ${ }^{a}$ & Period & Organ & Cultivar & Location \\
\hline \multirow[t]{12}{*}{ Transposa } & 53,55 & Harvest & Berry & Sémillon & Sauternes \\
\hline & $110,112,113$ & Veraison & Berry & Sauvignon & Pessac-Léognan \\
\hline & 160,163 & Preveraison & Berry & Sémillon & Pessac-Léognan \\
\hline & 193 & Preveraison & Leaf & Sémillon & Pessac-Léognan \\
\hline & 213 & Veraison & Berry & Sémillon & Pessac-Léognan \\
\hline & 225 & Veraison & Leaf & Sémillon & Pessac-Léognan \\
\hline & 234 & Harvest & Berry & Sémillon & Pessac-Léognan \\
\hline & 314 & Harvest & Leaf & Sauvignon & Entre-Deux-Mers \\
\hline & 326 & Bloom & Blossom & Merlot & Médoc, St-Julien \\
\hline & 332 & Bloom & Leaf & Merlot & Médoc, St-Julien \\
\hline & 343,344 & Harvest & Berry & Merlot & Médoc, St-Julien \\
\hline & $49^{\mathrm{b}}$ & Harvest & Berry & Sémillon & Sauternes \\
\hline \multirow[t]{7}{*}{ Vacuma } & $80^{c}$ & Preveraison & Berry & Sauvignon & Pessac-Léognan \\
\hline & $106^{\mathrm{c}}, 111^{\mathrm{c}}$ & Veraison & Berry & Sauvignon & Pessac-Léognan \\
\hline & $299^{c}$ & Harvest & Berry & Sauvignon & Entre-Deux-Mers \\
\hline & $307,310^{\mathrm{c}}$ & Harvest & Leaf & Sauvignon & Entre-Deux-Mers \\
\hline & 322 & Bloom & Blossom & Merlot & Médoc, St-Julien \\
\hline & 329 & Bloom & Leaf & Merlot & Médoc, St-Julien \\
\hline & 351,357 & Harvest & Leaf & Merlot & Médoc, St-Julien \\
\hline
\end{tabular}

a $B$. cinerea isolates were assessed for all phenotypic characteristics of virulence on leaf and mycelial growth as previously published (34) and virulence on berry and fungicide sensitivity unless indicated.

${ }^{\mathrm{b}}$ Not assayed for virulence on leaves.

${ }^{c}$ Assayed for grape berry virulence only. 
vacuma isolation rate on leaves was higher than that on berries. At this point, vacuma always comprised more than $10 \%$ of the isolates from leaves.

Virulence. The two genetic types, vacuma and transposa, differed significantly in virulence with respect to disease incidence and disease severity. For each virulence component, ANOVAs were performed at bunch closure, mid-veraison, and maturity. The genetic types were always significantly different in incidence $(P=$ $0.004,0.012$, and 0.001 , respectively) as well as in severity $(P=$ $0.045,0.004$, and 0.023 , respectively). Transposa isolates were significantly more virulent than were vacuma isolates at every developmental stage of grape berries tested (Fig. 2). The two grape cultivars were significantly different in susceptibility when incidence data were analyzed $(P \leq 0.001)$, except at bunch closure $(P=0.51)$, and severity data were analyzed $(P \leq 0.002)$. Cv. Merlot was generally more susceptible than cv. Sauvignon (Fig. 2).

Sensitivity to fungicides. All isolates tested were resistant to at least one of the three fungicides tested (Table 3). The six resistance profiles obtained (Table 3 ) allowed us to define three multiresistance levels: mono-resistant isolates (M), resistant to only one fungicide; bi-resistant isolates (B), resistant to two fungicides; and tri-resistant isolates $(\mathrm{T})$, resistant to the three fungi-

\section{Médoc}
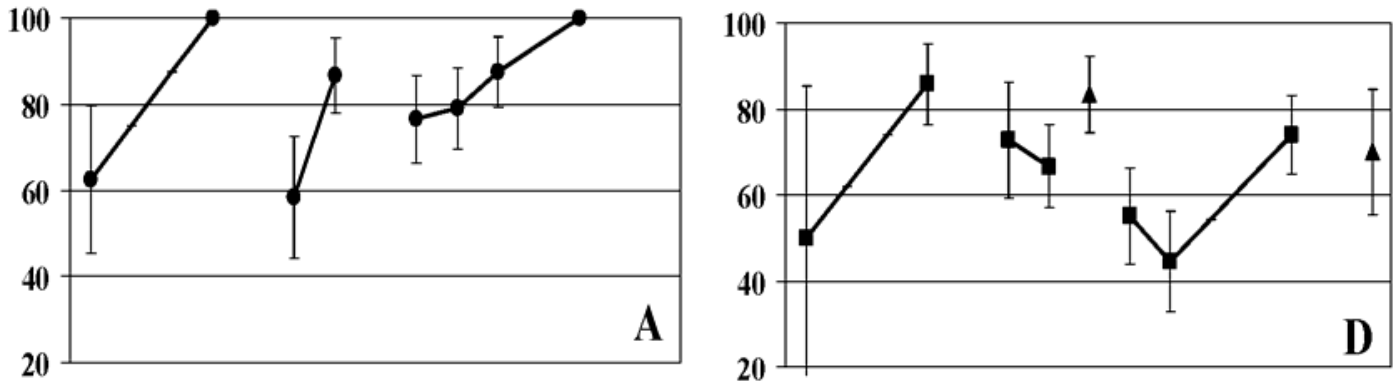

\section{Graves}
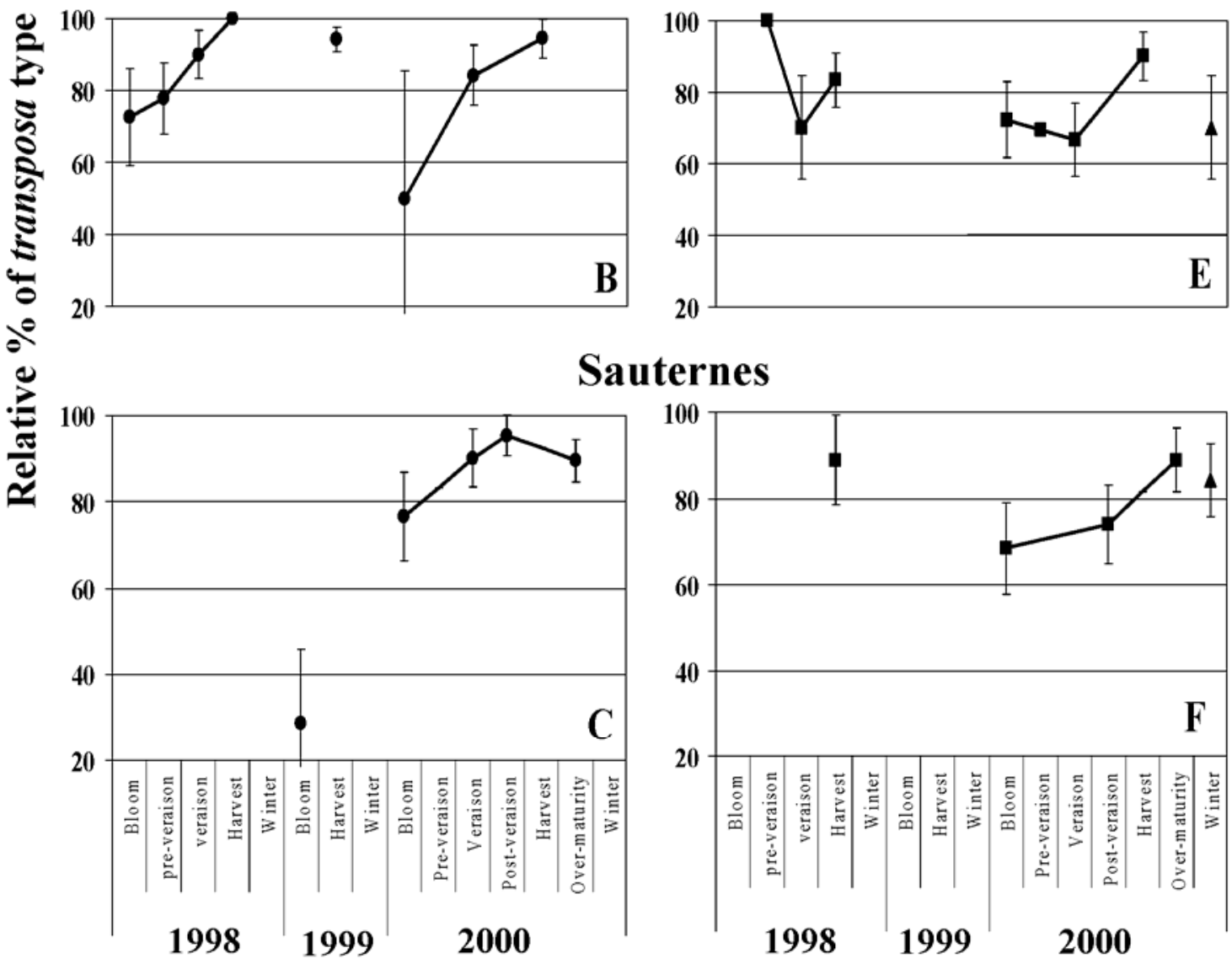

\section{Sauternes}

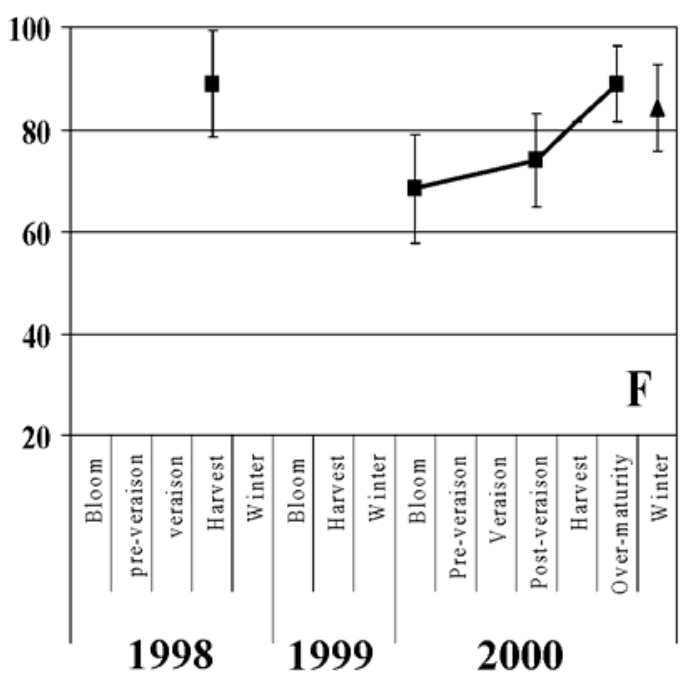

Transposa on reproductive organs

Transposa on leaves

Transposa on woody canes

Fig. 1. Change in the relative percentage (p) of the transposa isolates over time during 3 years $(1998,1999$, and 2000). The relative frequency in percentage of the vacuma isolates can be directly deduced $(100-$ p). Data issued from reproductive organs (flower and then berry) in three Bordeaux vineyards plots. A, Medoc, B, Graves, and $\mathbf{C}$, Sauternes and from leaf and woody cane in the same plots (D, E, and $\mathbf{F}$, respectively). All "Group I" isolates were removed from the analysis. 
cides. Most vacuma isolates were M (72.7\%); conversely, most of the transposa isolates were $\mathrm{B}$ and $\mathrm{T}(73.7 \%)$. The frequency distributions were significantly different $\left(\chi^{2}=7.06\right.$, df $=2, P=$ $0.029)$ between the two genetic types with 8 and $5 \mathrm{M}$ isolates, 3 and $9 \mathrm{~B}$ isolates, and 0 and $5 \mathrm{~T}$ isolates for vacuma and transposa, respectively. The frequency of isolates resistant to vinclozolin was significantly greater $\left(\chi^{2}=4.74, \mathrm{df}=1, P=0.029\right)$ in transposa $(68.4 \%)$ than it was in vacuma $(27.3 \%)$.

Relationships between sensitivity to fungicides, mycelial growth, and virulence. When vacuma and transposa were analyzed together or separately, significant correlations were established between the different phenotypic characteristics (Table 4). Globally and within the vacuma type, the virulence index on leaf was significantly and positively correlated with every virulence index on grape berry. Mycelial growth was significantly but negatively, correlated with all the virulence indices on berry or on leaf when considering the overall population (Table 4; Fig. 3). A similar, highly significant negative correlation between foliar virulence and mycelial growth was also detected for transposa ( $r=$ -0.63 ). Furthermore, mycelial growth was significantly and negatively correlated (Table 4) with double resistance to carbendazim and vinclozolin $(r=-0.40)$ and the multi-resistance level $(r=$
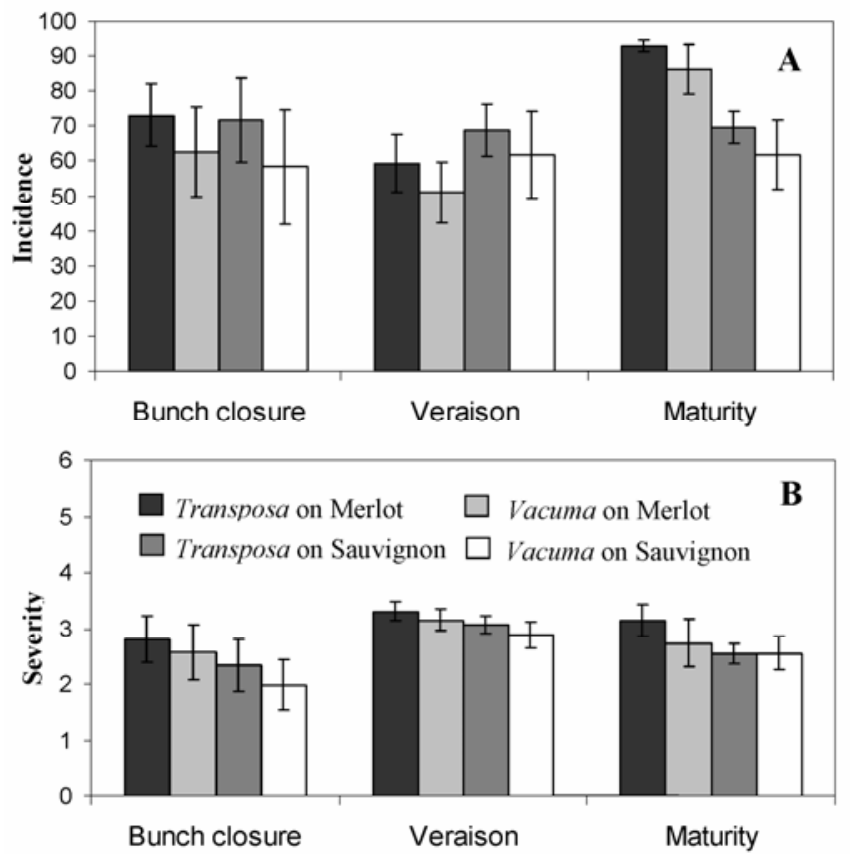

Fig. 2. Mean virulence of the two genetic types, vacuma and transposa, on cvs. Merlot and Sauvignon grape berries at three different phenological stages. $\mathbf{A}$, Incidence $=$ mean percentage of rotten berries. $\mathbf{B}$, Severity $=$ mean rotten surface area per berry according to a visual semiquantitative graded scale in which $0=$ healthy, $1=10 \%$ rotten and not sporulating, $2=25 \%, 3=50 \%, 4=$ $75 \%, 5=$ totally rotten sometimes sporulating slightly, and $6=$ totally rotten and sporulating).
-0.37). Last, there was only one significant relationship between one virulence index and fungicide resistance. Within the vacuma type, a positive significant correlation was detected $(r=0.68)$ between foliar virulence and resistance to carbendazim and vinclozolin (Table 4).

\section{DISCUSSION}

In this paper, we have studied changes in the isolation frequency of the major genetic types of $B$. cinerea over time in French vineyards. The epidemics of bunch rot were clearly dominated by Group II isolates. Group I isolates were found only sporadically, accounting for $2.5 \%$ of the total population. Detected mostly on leaves and blossoms, they were absent on maturing grape berries, which is in contrast to the vineyards of the Champagne Region where, at harvest in 2001 and 2002, the Group I isolates comprised approximately $6 \%$ of the whole population (29). Within Group II isolates, the relative frequencies of the vacuma and transposa types were highly dependent on the phenological stage of the vine and the organs infected. Isolates of both types were detected on every organ studied, suggesting no strict organ or tissue specialization. However, transposa was always the dominant genetic type whatever the organ which indicates an improved adaptation for developing in the grapevine ecosystem. Giraud et al. and Muñoz et al. $(16,40)$ have suggested that the two genetic types might even exhibit differences in host specificity. Our study shows clearly that the rigorous testing of such hypothesis will require the monitoring of genetic types over time and on different host organs. After reaching a maximum at flowering, the frequency of vacuma isolates decreased from blossom to harvest on leaves and reproductive organs (bloom followed by berries). The similarity in trends detected on different cultivars, at different sites, and in different years in this study together with corroborative observations in the Champagne vineyards (17), suggests that these dynamic patterns are a general feature of epidemics in the viticultural regions of Bordeaux and Champagne.

We consider three mechanisms that may account for the observed differences in the dynamics of the genetic types transposa and vacuma; (i) different saprophytic and parasitic capability, (ii) differential response to changing environmental stress, and (iii) historical or external influence of anti-Botrytis fungicides. $B$. cinerea is well documented as a capable saprotroph and parasite, often using exogenous, moribund nutrients to attack healthy organs $(57,39)$. Our controlled-environment studies demonstrate clearly that vacuma is characterized by higher saprotrophic capability, inferred from a higher growth rate in culture and reduced pathogenicity on grape berries. Because of the abundance of necrotic floral debris in the vineyards, the end of flowering represents an important epidemiological stage for B. cinerea $(24,42,57)$ that might favor the more saprotrophically able vacuma isolates (34). This would account for the higher frequency of isolation of vacuma isolates from senescent floral parts at the end of flowering (between 23.5 and $71.4 \%$ ). A similar ability to bulk-up sapro-

TABLE 3. Fungicide resistance profiles of 30 Botrytis cinerea isolates (11 vacuma and 19 transposa) toward carbendazim, diethofencarb, and vinclozolin

\begin{tabular}{|c|c|c|c|c|c|}
\hline Carbendazima ${ }^{\mathrm{a}}$ & Diethofencarb $^{\mathrm{a}}$ & Vinclozolin $^{\mathrm{a}}$ & Multiresistance levels ${ }^{\mathrm{b}}$ & vacuma isolates no. $(\%)^{\mathrm{c}}$ & transposa isolates no. $(\%)^{\mathrm{c}}$ \\
\hline $\mathrm{R}$ & $\mathrm{S}$ & $\mathrm{S}$ & 1 & $1(9.1 \%)$ & $0(0 \%)$ \\
\hline $\mathrm{S}$ & $\mathrm{R}$ & $\mathrm{S}$ & 1 & $7(63.6 \%)$ & $5(26.3 \%)$ \\
\hline $\mathrm{R}$ & $\mathrm{S}$ & $\mathrm{R}$ & 2 & $0(0 \%)$ & $2(10.5 \%)$ \\
\hline $\mathrm{S}$ & $\mathrm{R}$ & $\mathrm{R}$ & 2 & $3(27.3 \%)$ & $6(31.6 \%)$ \\
\hline $\mathrm{R}$ & $\mathrm{R}$ & $\mathrm{R}$ & 3 & $0(0 \%)$ & $5(26.3 \%)$ \\
\hline
\end{tabular}

${ }^{a} \mathrm{~S}=$ sensitive and $\mathrm{R}=$ resistant. For carbendazim and diethofencarb, the discriminatory concentration which inhibits the mycelial growth was $10 \mathrm{mg} / \mathrm{l}$ on MPG medium. For vinclozolin, the discriminatory concentration which inhibits the conidial germination was $5 \mathrm{mg} / \mathrm{l}$ on MPG medium.

b $1=$ Mono-resistant isolates (M), resistant to only one fungicide, $2=$ bi-resistant isolates (B), resistant to two fungicides, and $3=$ tri-resistant isolates $(\mathrm{T})$, resistant to the three fungicides tested.

c Corresponding percentages are relative percentages within each type, vacuma and transposa, respectively. 
trophically prior to infection has been described for the colonization of $B$. cinerea on many other plant hosts such as strawberry, raspberry, almond, apricot, and apple $(43,45,54)$. In contrast, during the summer months, the increased scarcity of these forms of substrate may account for the decrease in frequency of vacuma isolates until harvest, in this case to values less than $13.3 \%$ on mature berries. Low levels of saprotrophic colonization have been recorded for $B$. cinerea maintained on leaves damaged by routine cultural operations and on berries damaged by grape berry moth larvae $(10,11)$. Saprotrophy may also account for differences in population dynamics between seasons. From autumn to flowering in the subsequent season, there was a gradual increase in frequency of vacuma isolates with intermediate isolation rates from sclerotia in winter, i.e., between 15.8 and $30 \%$. Out of season, the vacuma inoculum may originate and multiply from plant debris on the soil within vineyards, but also from other hosts outside the grapevine plots (16). In contrast to vacuma, we have demonstrated the lower saprotrophic capability and enhanced pathogenicity of the transposa genetic type on grape berries of cvs. Merlot and Sauvignon at the three developmental stages tested. During berry development, in the stages between shatter and veraison, grape berries show very low susceptibility to $B$. cinerea (21). Therefore, at the early stages before veraison, the grape berry colonization by isolates of higher pathogenicity should confer a major selective advantage for transposa. This should, in turn, contribute actively to the significant increase in frequency of this genetic type until harvest. Furthermore, significant negative correlations, consistent with earlier studies (34), were established between mycelial growth and virulence by considering the whole $B$. cinerea population as well as within the transposa genetic type alone. A similar correlation has been reported for another ascomycete fungus, Leptosphaeria maculans, causing the blackleg disease in crucifers, especially Brassica sp. (50) and

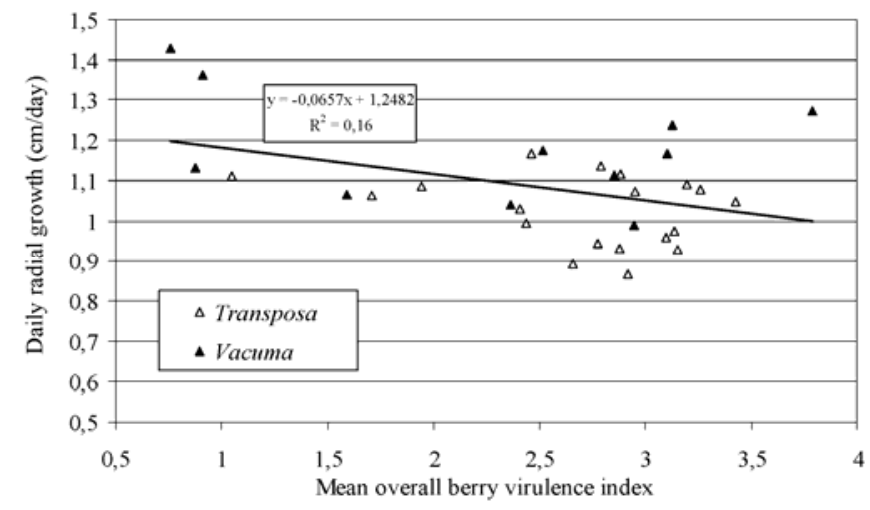

Fig. 3. Correlation between virulence on berries (overall berry virulence index) and mycelial growth. The regression equation was based on the data from all 30 Botrytis cinerea isolates.

TABLE 4. Pearson correlation matrix ${ }^{\mathrm{a}}$ between mycelial growth, virulence, and fungicide resistance in Botrytis cinerea

\begin{tabular}{|c|c|c|c|c|c|c|c|c|c|c|c|c|c|}
\hline & $\begin{array}{c}\text { Daily } \\
\text { radial } \\
\text { growth }\end{array}$ & $\begin{array}{c}\text { Foliar } \\
\text { virulence }\end{array}$ & $\begin{array}{c}\text { Berry } \\
\text { incidence }\end{array}$ & $\begin{array}{c}\text { Berry } \\
\text { severity }\end{array}$ & $\begin{array}{c}\text { Overall } \\
\text { berry } \\
\text { virulence }\end{array}$ & $\begin{array}{c}\mathrm{C} \\
\text { resistance }\end{array}$ & $\begin{array}{c}\mathrm{D} \\
\text { resistance }\end{array}$ & $\begin{array}{c}\mathrm{V} \\
\text { resistance }\end{array}$ & $\begin{array}{c}\mathrm{CD} \\
\text { resistance }\end{array}$ & $\begin{array}{c}\mathrm{CV} \\
\text { resistance }\end{array}$ & $\begin{array}{c}\mathrm{DV} \\
\text { resistance }\end{array}$ & $\begin{array}{c}\text { Triple- } \\
\text { resistance }\end{array}$ & $\begin{array}{l}\text { Multi- } \\
\text { resistance } \\
\text { level }\end{array}$ \\
\hline $\begin{array}{l}\text { Daily radial } \\
\text { growth }\end{array}$ & $\ldots$ & & & & & & & & & & & & \\
\hline $\begin{array}{l}\text { Foliar } \\
\text { virulence }^{b}\end{array}$ & $\begin{array}{l}-0.42 * \\
-\mathbf{0 . 6 3} * *\end{array}$ & $\ldots$ & & & & & & & & & & & \\
\hline $\begin{array}{l}\text { Berry } \\
\text { incidence }^{c}\end{array}$ & $-0.37 *$ & $\begin{array}{l}0.42 * \\
\underline{0.85} * *\end{array}$ & $\ldots$ & & & & & & & & & & \\
\hline $\begin{array}{l}\text { Berry } \\
\text { severity }\end{array}$ & $-0.46^{*}$ & $\begin{array}{l}0.56 * * \\
\underline{0.80}\end{array}$ & $\begin{array}{l}0.84 * * \\
0.84 * * \\
\mathbf{0 . 8 3} * *\end{array}$ & $\ldots$ & & & & & & & & & \\
\hline $\begin{array}{l}\text { Overall berry } \\
\text { virulence }^{c}\end{array}$ & $-0.40 *$ & $\begin{array}{l}0.49 * * \\
\underline{0.84} * *\end{array}$ & $\begin{array}{l}0.96 * * \\
0.96 * * \\
\mathbf{0 . 9 6} * *\end{array}$ & $\begin{array}{l}0.95 * * \\
0.95 * * \\
\mathbf{0 . 9 5} * *\end{array}$ & $\ldots$ & & & & & & & & \\
\hline C resistance ${ }^{\mathrm{d}}$ & -0.31 & 0.30 & 0.23 & 0.19 & 0.21 & $\ldots$ & & & & & & & \\
\hline D resistance ${ }^{\mathrm{d}}$ & 0.15 & -0.10 & -0.21 & -0.25 & -0.25 & $\begin{array}{l}-0.51 * * \\
-1.00 * *\end{array}$ & $\ldots$ & & & & & & \\
\hline V resistance ${ }^{\mathrm{d}}$ & -0.34 & 0.23 & 0.14 & 0.06 & 0.08 & 0.32 & -0.09 & $\ldots$ & & & & & \\
\hline $\begin{array}{l}\mathrm{CD} \\
\text { resistance }\end{array}$ & -0.25 & 0.27 & 0.11 & 0.03 & 0.05 & $\begin{array}{l}0.76 * * \\
\mathbf{0 . 8 0} * *\end{array}$ & 0.17 & 0.30 & $\ldots$ & & & & \\
\hline $\begin{array}{l}\mathrm{CV} \\
\text { resistance }\end{array}$ & $-0.40^{*}$ & $\begin{array}{l}0.32 \\
\underline{0.68} *\end{array}$ & 0.23 & 0.15 & 0.17 & $\begin{array}{l}0.79 * * \\
\mathbf{0 . 8 3} * *\end{array}$ & -0.36 & $\begin{array}{l}0.83 * * \\
0.81 * * \\
\mathbf{0 . 8 1} * *\end{array}$ & $\begin{array}{l}0.64 * * \\
0.63 * *\end{array}$ & $\ldots$ & & & \\
\hline $\begin{array}{l}\mathrm{DV} \\
\text { resistance }\end{array}$ & -0.22 & 0.15 & 0.01 & -0.08 & -0.07 & $\begin{array}{c}0.01 \\
-0.65 *\end{array}$ & $\begin{array}{l}0.46^{*} \\
\underline{0.65}\end{array}$ & $\begin{array}{l}0.84 * * \\
\mathbf{0 . 8 0} * *\end{array}$ & 0.36 & $\begin{array}{c}0.55^{* *} \\
\mathbf{0 . 5 2} *\end{array}$ & $\ldots$ & & \\
\hline $\begin{array}{l}\text { Triple- } \\
\text { resistance }\end{array}$ & -0.14 & 0.09 & 0.06 & -0.03 & -0.01 & $\begin{array}{l}0.68 * * \\
\mathbf{0 . 7 0} * *\end{array}$ & 0.15 & $0.42 *$ & $\begin{array}{l}0.89 * * \\
\mathbf{0 . 8 8} * *\end{array}$ & $\begin{array}{l}0.67 * * \\
0.68 * *\end{array}$ & $\begin{array}{l}0.45^{*} \\
\mathbf{0 . 5 1} *\end{array}$ & $\ldots$ & \\
\hline $\begin{array}{l}\text { Multi- } \\
\text { resistance } \\
\text { level }^{\mathrm{g}}\end{array}$ & $-0.37 *$ & 0.31 & 0.16 & 0.06 & 0.08 & $\begin{array}{l}0.64 * * \\
\mathbf{0 . 7 3} * *\end{array}$ & 0.03 & $0.85^{* *} *$ & $\begin{array}{l}0.76 * * \\
0.78 * *\end{array}$ & $\begin{array}{l}0.92 * * \\
\underline{0.81} * * \\
\mathbf{0 . 9 2} * *\end{array}$ & $\begin{array}{l}0.78 * * \\
0.87 * * \\
\mathbf{0 . 7 3} * *\end{array}$ & $\begin{array}{l}0.78 * * \\
\mathbf{0 . 8 2} * *\end{array}$ & $\ldots$ \\
\hline
\end{tabular}

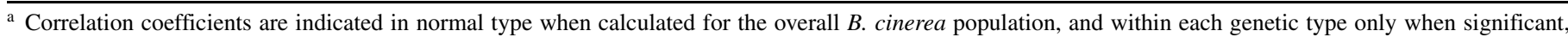

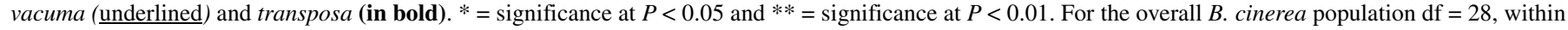
transposa type $\mathrm{df}=17$, and within vacuma type $\mathrm{df}=9$, except for correlations involving foliar virulence with $\mathrm{df}=25$, $\mathrm{df}=15$, and $\mathrm{df}=8$, respectively.

b The foliar virulence index was calculated using data from pathogenicity tests on two hosts, grapevine and tobacco (34).

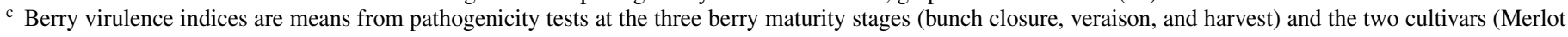
and Sauvignon).

d C, D, and V are abbreviations respectively for carbendazim, diethofencarb, and vinclozolin.

e CD, CV, and DV are double resistance abbreviations for carbendazim-diethofencarb, carbendazim-vinclozolin, and diethofencarb-vinclozolin, respectively.

$\mathrm{f}$ Triple resistance means isolates resistant to carbendazim, diethofencarb and vinclozolin simultaneously.

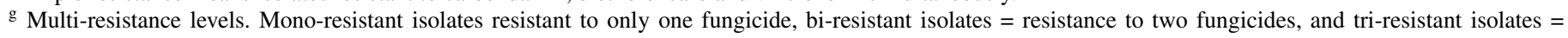
resistance to the three fungicides tested. 
Microdochium nivale (3). Such consistency might suggest a common genetic mechanism involved in the control of mycelial growth and pathogenicity. For example, in Magnaporthe grisea, $G$ protein $\alpha$ subunit genes are involved in signal transduction pathways that control vegetative growth, conidiation, conidium attachment, appressorium formation, mating, and pathogenicity (32).

That temporal change in the relative frequencies of the two B. cinerea genetic types, vacuma and transposa, might simply be caused by changing environmental conditions cannot be discounted. Response to temperature might be considered the most likely candidate, assuming the possibility of better adaptation of transposa to high summer temperatures. However, the isolates of the two types display very similar thermic optima with no difference in mycelial growth rate at $28^{\circ} \mathrm{C}$ (34). Therefore, high temperatures during the summer $\left(28^{\circ} \mathrm{C}\right.$ is often reached in Bordeaux) at the berry level (12) are unlikely to account for the shift in population frequencies between vacuma and transposa. Nevertheless, other climatic components such as humidity or thermal shock, which have not yet been investigated, could still play a role in conidial or mycelial survival and hence the balance between vacuma and transposa.

We have also considered a differential response to fungicides as a possible mechanism for explaining the dynamical changes in frequencies of the different genetic types. Concerning Group I, every isolate was characterized by resistance to the fungicide fenhexamid (hydroxyanilide) that was detected by monitoring studies of the $B$. cinerea population before commercial introduction of this fungicidal ingredient in French vineyards during 2000 $(29,52)$. The selection of fenhexamid-resistant isolates can occur rapidly, as was demonstrated in Switzerland, where the level of the resistant isolates increased from 0 to $100 \%$ in 4 years (2). For this reason, increasing fenhexamid applications in vineyards from 2000 , could lead to a significant increase in the frequency of Group I isolates. As for Group II, we have confirmed the significant differences in fungicide resistance profiles between vacuma and transposa. The transposa isolates were more multiresistant and showed, as they did in Champagne (16), a greater frequency of resistant isolates to vinclozolin (dicarboximide). In French vineyards, dicarboximide fungicides are usually applied at or after veraison and targeted at the cluster zone. They were used on our experimental plots in the years before the study and in the surrounding vine plots during the period of study. That dicarboximide applications might have caused the increase in transposa population after veraison is not likely because this will depend on (i) differential selection for transposa isolates, (i.e., transposa is innately more likely to produce resistance to dicarboximide) and (ii) that the epidemics in our experimental plots, untreated with fungicides, were dominated by the influx of inoculum from surrounding areas under fungicide management. The possibility of transposa isolates being physiologically more likely to develop fungicide resistance, in association with increased virulence, could be based on MDR (multi-drug resistance) systems $(7,30)$. Efflux of cytotoxic drugs due to MDR systems might also result in increased virulence by limiting the accumulation of plant defense compounds (e.g., phytoalexins) or increasing the secretion of pathogenicity factors $(7,51)$. The role of such mechanisms in the population dynamics of Botrytis types warrants further investigation. However, the most likely explanation for the observed resistance profiles is that the transposa isolates, because they predominate markedly on maturing grape berries after veraison, have been exposed to higher fungicide pressure from dicarboximide, resulting in a greater frequency of vinclozolin-resistant isolates.

We have also investigated the potential interactions between fungicide resistance and fitness measures as well as correlations among these phenotypic characteristics. We did not detect any significant negative correlations between fungicide resistance and virulence. Therefore, our virulence data did not demonstrate a fitness cost associated with fungicide resistance. This is consistent with the results of other studies concerning dicarboximide or benzimidazole resistance in relation to lesion growth rate, area under the disease progress curve, mycelial survival, and sporulation intensity $(36,47,48)$. On the contrary, the only correlations we established were positive. Within the vacuma type only, resistance to carbendazim and vinclozolin fungicides was associated with an increased virulence. As hypothesized above for the case of transposa isolates, the more virulent vacuma isolates, by occurring more often on leaves and berries after flowering, may have been exposed to higher fungicide pressure resulting in a greater rate of resistance to these fungicides. Within the $B$. cinerea population overall, the mycelial growth rate was significantly reduced for the isolates with multiple resistance, in particular, those resistant to dicarboximide and benzimidazole fungicides. However, this negative correlation was due to two opposed characteristics in the vacuma and transposa types: vacuma isolates showing a faster mycelial growth and a lower resistance level and vice versa for transposa. Thus, the correlation analysis further substantiates the hypothesis stating that fitness differences between resistant and sensitive isolates may be because of differences in the genetic background of the isolates rather than to a real fitness cost (44).

We conclude, therefore, that the Group I isolates may be considered to play only a minor role in the epidemiological process. As for Group II, differences in the saprotrophic and pathogenic ability of the two types combined with a switch in resource availability from dead to living tissues is the most likely mechanism accounting for the success of transposa isolates and the decline of vacuma isolates during the course of an epidemic. The relative importance of resource availability allowing saprotrophic development requires further investigation as far as population structure and dynamics are concerned. For example, this could be tested by altering the availability of floral material before and during senescence (during and after bloom). The hypothesis that differences in fungicide resistance are most likely only a consequence of these dynamics and are generated by the sequence in which fungicides are applied requires further testing. Finally, this study demonstrates clearly that the genetic structure of B. cinerea populations, together with their phenotypic characteristics and their potential role in Botrytis rot development, should be considered in studies concerning the quantitative epidemiology, fungicide antiresistance, and integrated pest management.

\section{ACKNOWLEDGMENTS}

We are indebted to J. Laville for her technical participation and to the viticulture managers for access to the experimental vineyards, Château Léoville Las Cases (St-Julien), Domaine INRA de Couhins (PessacLéognan), and Lafaurie-Peyraguey (Sauternes). Special thanks are also due to D. Bailey for helpful contributions and valuable comments during the writing and revision of this manuscript. This study was supported by research grants from INRA (AIP Ecopath) and the "Conseil Interprofessionnel du Vin de Bordeaux" (CIVB).

\section{LITERATURE CITED}

1. Albertini, C., Thebaud, G., Fournier, E., and Leroux, P. 2002. Eburicol $14 \alpha$-demethylase gene (CYP51) polymorphism and speciation in Botrytis cinerea. Mycol. Res. 106:1171-1178.

2. Baroffio, C. A., Siegfried, W., and Hilber, U. W. 2003. Long-term monitoring for resistance of Botryotinia fuckeliana to anilinopyrimidine, phenylpyrrole, and hydroxyanilide fungicides in Switzerland. Plant Dis. 87:662-666.

3. Brennan, J. M., Fagan, B., van Maanen, A., Cooke, B. M., and Doohan, F. M. 2003. Studies on in vitro growth and pathogenicity of European Fusarium fungi. Eur. J. Plant Pathol. 109:577-587.

4. Bulit, J., and Dubos, B. 1988. Botrytis bunch rot and blight. Pages 13-15 
in: Compendium of Grape Diseases. R. C. Pearson and A. C. Goheen, eds. The American Phytopathological Society, St. Paul, MN.

5. Büttner, P., Koch, F., Voigt, K., Quidde, T., Risch, S., Blaich, R., Brückner, B., and Tudzynski, P. 1994. Variations in ploidy among isolates of Botrytis cinerea: Implications for genetic and molecular analyses. Curr. Genet. 25:445-450.

6. Chardonnet, C. O., Sams, C. E., Trigiano, R. N., and Conway, W. S. 2000. Variability of three isolates of Botrytis cinerea affects the inhibitory effects of calcium on this fungus. Phytopathology 90:769-774.

7. De Waard, M. A. 1997. Significance of ABC transporter in fungicide sensitivity and resistance. Pestic. Sci. 51:271-275.

8. Di Lenna, P., Marciano, P., and Magro, P. 1981. Comparative investigation on morphological and physiological features of three isolates of Botrytis cinerea. Phytopathol. Z. 100:203-211.

9. Diolez, A., Marches, F., Fortini, D., and Brygoo, Y. 1995. Boty, a longterminal-repeat retroelement in the phytopatogenic fungus Botrytis cinerea. Appl. Environ. Microbiol. 61:103-108.

10. Fermaud, M., and Le Menn, R. 1989. Association of Botrytis cinerea with grape berry moth larvae. Phytopathology 79:651-656.

11. Fermaud, M., and Le Menn, R. 1992. Transmission of Botrytis cinerea to grapes by grape berry moth larvae. Phytopathology 82:1393-1398.

12. Fermaud, M., Limiñana, J. M., Froidefond, G., and Pieri, P. 2001. Grape cluster microclimate and architecture affect severity of Botrytis rot of ripening berries. IOBC/WPRS Bull. 24:7-10.

13. Fermaud, M., and Pieri, P. 2000. Importance of different epidemiological stages of Botrytis rot in the vineyard and role of the microclimate. XIIth Int. Botrytis Symposium.

14. Fournier, E., Levis, C., Fortini, D., Leroux, P., Giraud, T., and Brygoo, Y. 2003. Characterization of $\mathrm{Bc}-h c h$, the Botrytis cinerea homolog of the Neurospora crassa het-c vegetative incompatibility locus, and its use as a population marker. Mycologia 95:251-261.

15. Giraud, T., Fortini, D., Levis, C., and Brygoo, Y. 1998. The minisatellite MSB1, in the fungus Botrytis cinerea, probably mutates by slippage. Mol. Biol. Evol. 15:1524-1531.

16. Giraud, T., Fortini, D., Levis, C., Lamarque, C., Leroux, P., LoBuglio, K., and Brygoo, Y. 1999. Two sibling species of the Botrytis cinerea complex, transposa and vacuma, are found in sympatry on numerous host plants. Phytopathology 89:967-973.

17. Giraud, T., Fortini, D., Levis, C., Leroux, P., and Brygoo, Y. 1997. RFLP markers show genetic recombination in Botrytinia fuckeliana (Botrytis cinerea) and transposable elements reveal two sympatric species. Mol. Biol. Evol. 14:1177-1185.

18. Giraud, T., Fortini, D., Levis, C., Leroux, P., and Brygoo, Y. 1998. Plusieurs espèces cachées sous le nom de Botrytis cinerea! Phytoma, La défense des Végétaux 504:56-60.

19. Govrin, E. M., and Levine, A. 2000. The hypersensitive response facilitates plant infection by the necrotrophic pathogen Botrytis cinerea. Curr. Biol. 10:751-757.

20. Hansen, H. N., and Smith, R. E. 1932. The mechanism of variation in imperfect fungi: Botrytis cinerea. Phytopathology 22:953-964.

21. Hill G., Stellwaag-Kittler, F., Huth, G., and Schlösser, E. 1981. Resistance of grapes in different developmental stages to Botrytis cinerea. Phytopathol. Z. 102:328-338.

22. Hsiang, T., and Chastagner, G. A. 1991. Growth and virulence of fungicide-resistant isolates species of Botrytis. Can. J. Plant Pathol. 13:226231.

23. Jarvis, W. R. 1980. Epidemiology. Pages 219-250 in: The Biology of Botrytis. J. R. Coley-Smith, K. Verhoeff, and W. R. Jarvis, eds. Academic Press, New York.

24. Keller, M., Viret, O., and Cole, M. F. 2003. Botrytis cinerea infection in grape flowers: Defense reaction, latency, and disease expression. Phytopathology 93:316-322.

25. Kerssies, A., Bosker-van Zessen, A. I., Wegemakers, C. A. M., and van Kan, J. A. L. 1997. Variation in pathogenicity and DNA polymorphism among Botrytis cinerea isolates sampled inside and outside a glasshouse. Plant Dis. 81:781-786.

26. Krüger, B.-W., Etzel, W., and Goehrt, A. 1999. Fenhexamid - Ein neues Botrytizid aus einer neuen wirkstoffklasse. Pflanzenschutz-Nachr. Bayer 52:123-130.

27. Leroux, P., Chapeland, F., Arnold, A., and Gredt, M. 1998. Résistance de Botrytis cinerea aux fongicides - Du laboratoire au vignoble et vice versa. Phytoma, La défense des Végétaux 504:62-67.

28. Leroux, P., Chapeland, F., Desbrosses, D., and Gredt, M. 1999. Patterns of cross-resistance to fungicides in Botryotinia fuckeliana (Botrytis cinerea) isolates from french vineyards. Crop Prot. 18: 687-697.

29. Leroux, P., Fournier, E., Brygoo, Y., and Panon, M.-L. 2002. Biodiversité et variabilité chez Botrytis cinerea, l'agent de la Pourriture grise. Nouveaux résultats sur les espèces et les résistances. Phytoma, la Défense des Végétaux 554:38-42.
30. Leroux, P., Fritz, R., Debieu, D., Albertini, C., Lanen, C., Bach, J., Gredt, M., and Chapeland, F. 2002. Mechanisms of resistance to fungicides in field isolates of Botrytis cinerea. Pest Manag. Sci. 58:876-888.

31. Levis, C., Fortini, D., and Brygoo, Y. 1997. Flipper, a mobile Fot1-like transposable element in Botrytis cinerea. Mol. Gen. Genet. 254:674-680.

32. Liu, S., and Dean, R. A. 1997. G Protein $\alpha$ subunit genes control growth, development, and pathogenicity of Magnaporthe grisea. Mol. PlantMicrobe Interact. 10:1075-1086.

33. Martinez, F. 2002. Etude de la structure génétique et des aptitudes biologiques des populations de Botrytis cinerea Pers. Dans le vignoble bordelais. Ph.D. thesis. University of Bordeaux II, Bordeaux, France.

34. Martinez, F., Blancard, D., Lecomte, P., Levis, C., Dubos, B., and Fermaud, M. 2003. Phenotypic differences between vacuma and transposa types of Botrytis cinerea. Eur. J. Plant Pathol. 109:479-488.

35. Möller, E, Bahnweg, M. G., Sandermann, H., and Geige, H. H. 1992. A simple and efficient protocol for isolation of high molecular weight DNA from filamentous fungi fruit bodies and infected plant tissues. Nucleic Acids Res. 20:6115-6116.

36. Moorman, G. W., and Lease, R. J. 1992. Benzimidazole- and dicarboximide-resistant Botrytis cinerea from Pennsylvania greenhouses. Plant Dis. 76:477-480.

37. Movahedi, S., and Heale, J. B. 1990. The role of aspartic proteinase and endo-pectin lyase enzymes in the primary stages of infection and pathogenesis of various host tissues by different isolates of Botrytis cinerea Pers. ex. Pers. Physiol. Mol. Plant Pathol. 36:303-324.

38. Moyano, C., Alfonso, C., Gallego, J., Raposo, R., and Melgarejo, P. 2003. Comparison of RAPD and AFLP marker analysis as a means to study the genetic structure of Botrytis cinerea populations. Eur. J. Plant Pathol. 109:515-522.

39. Moyano, C., and Melgarejo, P. 2002. Survival of Botrytis cinerea in soil in South-Eastern Spain. J. Phytopathol. 150:536-540.

40. Muñoz, G., Hinrichsen, P., Brygoo, Y., and Giraud, T. 2002. Genetic characterisation of Botrytis cinerea populations in Chile. Mycol. Res. 106:594-601.

41. Nair, N. G. 1996. Quantitative epidemiology as an aid to measuring disease risk of Botrytis bunch rot of grapes. XIth Int. Botrytis Symposium.

42. Nair, N. G., Guilbaud-Oulton, S., Barchia, I., and Emmett, R. 1995. Significance of carryover inoculum, flower infection and latency on the incidence of Botrytis cinerea in berries of grapevines at harvest in New South Wales. Aust. J. Exp. Agric. 35:1177-1180

43. Ogawa, M. J., and English, H. 1960. Blossom blight and green fruit of almond, apricot and plum caused by Botrytis cinerea. Plant Dis. Rep. 44:265-268.

44. Peever, T. L., and Milgroom, M. G. 1994. Lack of correlation between fitness and resistance to sterol biosynthesis-inhibiting fungicides in Pyrenophora teres. Phytopathology 84:515-519.

45. Powelson, R. L. 1960. Initiation of strawberry fruit rot caused by Botrytis cinerea. Phytopathology 50:491-494.

46. Pugh, G. J. F. 1980 Strategies in fungal ecology. Trans. Br. Mycol. Soc. 75:1-14.

47. Raposo, R., Delcan, J., Gomez, V., and Melgarejo, P. 1996. Distribution and fitness of isolates of Botrytis cinerea with multiple fungicide resistance in Spanish greenhouses. Plant Pathol. 45:497-505.

48. Raposo, R., Gomez, V., Urrutia, T., and Melgarejo, P. 2000. Fitness of Botrytis cinerea associated with dicarboximide resistance. Phytopathology 90:1246-1249.

49. Ribéreau-Gayon, J., Ribéreau-Gayon, P., and Seguin, G. 1980. Botrytis cinerea in enology. Pages 251-274 in: The Biology of Botrytis. J. R. Coley-Smith, K. Verhoeff, and W. R. Jarvis, eds. Academic Press, New York.

50. Rouxel, T., Gall, C., and Balesdent, M. H. 1994. Du polymorphisme au complexe d'espèces: Combien d'agent pathogènes sont impliqués dans la nécrose du collet du colza? Agronomie 14:413-432.

51. Schoonbeek, H., Del Sorbo, G., and De Waard, M. A. 2001. The ABC transporter BcatrB affects the sensitivity of Botrytis cinerea to the phytoalexin resveratrol and the fungicide fenpiclonil. Mol. Plant-Microbe Interact. 14:562-571

52. Suty, A., Pontzen, R., and Stenzel, K. 1997. KBR 2738 - Mode d'action et sensibilité de Botrytis cinerea. Pages 561-568 in: Proc. Cinquième Conférence Internationale sur les Maladies des Plantes AFPP, Paris.

53. Thompson, J. R., and Latorre, B. A. 1999. Characterization of Botrytis cinerea from table grapes in Chile using RAPD-PCR. Plant Dis. 83: 1090-1094.

54. Tronsmo, A., and Raa, J. 1977. The life cycle of the dry eye rot pathogen Botrytis cinerea Pers. on apple. Phytopathol. Z. 89:203-207.

55. Vallejo, I., Santos, M., Cantoral, J. M., Collado, I. G., and Rebordinos, L. 1996. Chromosomal polymorphism in Botrytis cinerea. Hereditas 124: 31-38.

56. Van der Vlugt-Bergmans, C. J. B., Brandwagt, B. F., Van't Klooster, J. W., 
Wagemakers, C. A. M., and Van Kan, J. A. L. 1993. Genetic variation and segregation of DNA polymorphism in Botrytis cinerea. Mycol. Res. 97:1193-1200.

57. Wolf, T. K., Baudoin, A. B. A. M., and Martinez-Ochoa, N. 1997. Effect of debris removal from fruit clusters on botrytis bunch rot of Chardonnay grapes. Vitis 36:27-33.
58. Yourman, L. F., Jeffers, S. N., and Dean, R. A. 2001. Phenotype instability in Botrytis cinerea in the absence of benzimidazole and dicarboximide fungicides. Phytopathology 91:307-315.

59. Ziogas, B. N., Markoglou, A. N., and Malandrakis, A. A. 2003. Studies on the inherent resistance risk to fenhexamid in Botrytis cinerea. Eur. J. Plant Pathol. 109:311-317. 